\title{
Expression and biological activity of X-linked inhibitor of apoptosis (XIAP) in human malignant glioma
}

\author{
Bettina Wagenknecht ${ }^{1}$, Tamara Glaser ${ }^{1}$, Ulrike Naumann ${ }^{1}$, \\ Sebastian Kügler², Stefan Isenmann², Mathias Bähr², \\ Robert Korneluk ${ }^{3}$, Peter Liston ${ }^{3}$ and Michael Weller ${ }^{*, 1}$ \\ ${ }^{1}$ Laboratory of Molecular Neuro-Oncology, Hoppe-Seyler-Strasse 3, Germany; \\ ${ }^{2}$ Laboratory of Neurodegeneration, Department of Neurology, University of \\ Tüebingen, School of Medicine, Hoppe-Seyler-Strasse 3, Germany; \\ ${ }^{3}$ Molecular Genetics Research Laboratory, Children's Hospital and Apoptogen \\ Inc., Ottawa, Canada \\ * corresponding author: Michael Weller, M.D., Department of Neurology, \\ University of Tübingen, School of Medicine, Hoppe-Seyler-Strasse 3, 72076 \\ Tübingen, Germany. tel: 497071298 2141; fax: 49707129 5260; \\ e-mail: michael.weller@uni-tuebingen.de
}

Received 10.11.98; revised 19.1.99; accepted 4.2.99

Edited by C.J. Thiele

\begin{abstract}
The inhibitor-of-apoptosis (IAP) proteins are a novel family of antiapoptotic proteins that are thought to inhibit cell death via direct inhibition of caspases. Here, we report that human malignant glioma cell lines express XIAP, HIAP-1 and HIAP-2 mRNA and proteins. NAIP was not expressed. IAP proteins were not cleaved during CD95 ligand (CD95L)-induced apoptosis, and loss of IAP protein expression was not responsible for the potentiation of CD95L-induced apoptosis when protein synthesis was inhibited. LN-18 cells are highly sensitive to CD95-mediated apoptosis, whereas LN-229 cells require co-exposure to $\mathrm{CD} 95 \mathrm{~L}$ and a protein synthesis inhibitor, $\mathrm{CHX}$, to acquire sensitivity to apoptosis. Adenoviral XIAP gene transfer blocked caspase 8 and 3 processing in both cell lines in the absence of $\mathrm{CHX}$. Apoptosis was blocked in the absence and in the presence of $\mathrm{CHX}$. However, XIAP failed to block caspase 8 processing in $\mathrm{LN}-229$ cells in the presence of $\mathrm{CHX}$. There was considerable overlap of the effects of XIAP on caspase processing with those of BCL-2 and the viral caspase inhibitor crm-A. These data define complex regulatory mechanisms for CD95-mediated apoptosis in glioma cells and indicate that there may be a distinct pathway of death receptor-mediated apoptosis that is readily activated when protein synthesis is inhibited. The constitutive expression of natural caspase inhibitors may play a role in the resistance of these cells to apoptotic stimuli that directly target caspases, including radiochemotherapy and immunemediated tumor cell lysis.
\end{abstract}

Keywords: XIAP; CD95 (APO-1, Fas); glioma; apoptosis

Abbreviations: CD95L, CD95 ligand; CHX, cycloheximide; XIAP, X-linked inhibitor of apoptosis; IAP, inhibitor-of-apoptosis proteins; $\mathrm{MOI}$, multiplicity of infection; NAIP, neuronal apoptosis-inhibitory protein; TNF, tumor necrosis factor

\section{Introduction}

Human malignant glioma cells are paradigmatic for their intrinsic resistance to multiple proapoptotic stimuli. The molceular basis of their resistance to apoptosis has not been fully elucidated. Several viruses have been shown to express inhibitors of apoptotic cell death which are thought to inhibit the death of infected cells while the virus is replicating. ${ }^{1}$ Some of these proteins, e.g., the adenoviral E1B protein and the Epstein Barr virus protein BHRF-1 (BCL-2 homologue open reading frame-1), may resemble the mammalian $B C L-2$ protein. $^{2}$ BCL-2 inhibits apoptosis, amongst others, by preventing the release of cytochrome $C$ from mitochondria which in turn would activate caspases. ${ }^{3,4}$ Other antiapoptotic factors such as the baculoviral p35 protein appear to have no structural mammalian counterpart. p35 acts via competitive inhibition of caspases. ${ }^{5}$ Another family of inhibitor-ofapoptosis proteins (IAP) has also been identified in baculoviruses. $^{6}$ Neuronal apoptosis-inhibitory protein (NAIP), a gene linked to spinal muscle atrophy, was the first human gene identified that showed sequence homology to genes coding for the viral IAP proteins. ${ }^{7}$ The NAIP protein is widely expressed in neurons in the rat central nervous system but not in glial cells in vivo. ${ }^{8}$ At least three further IAP genes with antiapoptotic properties were subsequently identified: HIAP-1, HIAP-2 and XIAP. ${ }^{9-11}$ Forced expression of NAIP inhibited cell death induced by serum deprivation or menadione in $\mathrm{CHO}$ cells and TNF/CHX-induced apoptosis in HeLa cells. The three novel mammalian IAP proteins inhibited cell death induced by serum deprivation or menadione but not staurosporine-induced apoptosis. Further, adenoviral NAIP gene transfer reduced ischaemic neuron loss in the hippocampus. ${ }^{12}$ XIAP, HIAP-1 and HIAP-2, but not NAIP, interfere with apoptosis at the level of caspase 3 and 7 processing. ${ }^{13,14}$ Further, these proteins have been shown to interact directly with reaper, a death-inducing protein in Drosophila. ${ }^{15}$

The same inhibitors of apoptosis were independently cloned by Vaux and colleagues ${ }^{11}$ who referred to these genes as MIHA (XIAP), MIHB (HIAPII) and MIHC (HIAPI). MIHA and MIHB, but not MIHC, inhibited apoptosis mediated by ectopic expression of caspase 1 in HeLa cells. Neither MIHA nor MIHB nor MIHC inhibited cell death induced by ectopic expression of FADD (Fasassociating protein with death domain) which forms part of the death-inducing signalling complex (DISC) of CD95mediated apoptosis. ${ }^{16}$ Further, MIHB and MIHC were shown to interact with TRAF-1 and TRAF-2 (TNF receptor-associated factor) in the yeast two-hybrid system. ${ }^{11}$ TRAF-1 and TRAF-2 are involved in survivalpromoting rather than cytotoxic signalling mediated by TNF receptors. ${ }^{17}$ Consistent with a role of nuclear factor (NF) $-\kappa B$ in TNF-induced stimulation or activation rather than TNF-induced cell death, the IAP-mediated protection from TNF cytotoxicity has been hypothesized to be 
controlled by NF- $\kappa$ B. ${ }^{18,19}$ Survivin, a human gene encoding a new apoptosis inhibitor with structural similarity to IAP, was recently identified. ${ }^{20}$ Survivin is unique in that it is expressed selectively in most common human cancers but not in normal adult tissue. ${ }^{21}$ Expression of the antiapoptotic survivin seems to correlate with an histologically more aggressive type and an unfavourable prognosis of neuroblastoma. ${ }^{22}$ Here, we have examined the expression and functional activity of IAP family proteins in human malignant glioma cells.

\section{Results}

\section{Expression of IAP family genes in human malignant glioma cell lines}

Total RNA from the 12 glioma cell lines was examined for the expression of IAP family genes by RT-PCR (Figure 1A, Table 1). XIAP, HIAP-1 and HIAP-2 mRNA were detected in all cell lines. At the protein level, XIAP, HIAP-1 and HIAP-2 were also detected in all cell lines (Figure 1B). Although the antibodies to HIAP-1 and HIAP-2 yielded a high background, adenoviral gene transfer of the respective IAP genes indicated which bands corresponded to the protein of interest. In contrast, NAIP protein was not detected in any of the cell lines using adenoviral NAIP gene transfer as a positive control (data not shown).

\section{IAP family proteins are not the target of $\mathrm{CHX}$ - dependent potentiation of CD95L-induced apoptosis of human glioma cells}

Since IAP are thought to inhibit apoptosis via direct inhibition of caspases ${ }^{13,14,23}$ and since caspase activation is required for CD95L-induced apoptosis of malignant glioma cells, ${ }^{24,25}$ we next examined the role of endogenous IAP in the apoptotic cell death of CD95L-treated LN-18 and LN-229 cells. First, we wished to examine whether IAP are potential

A
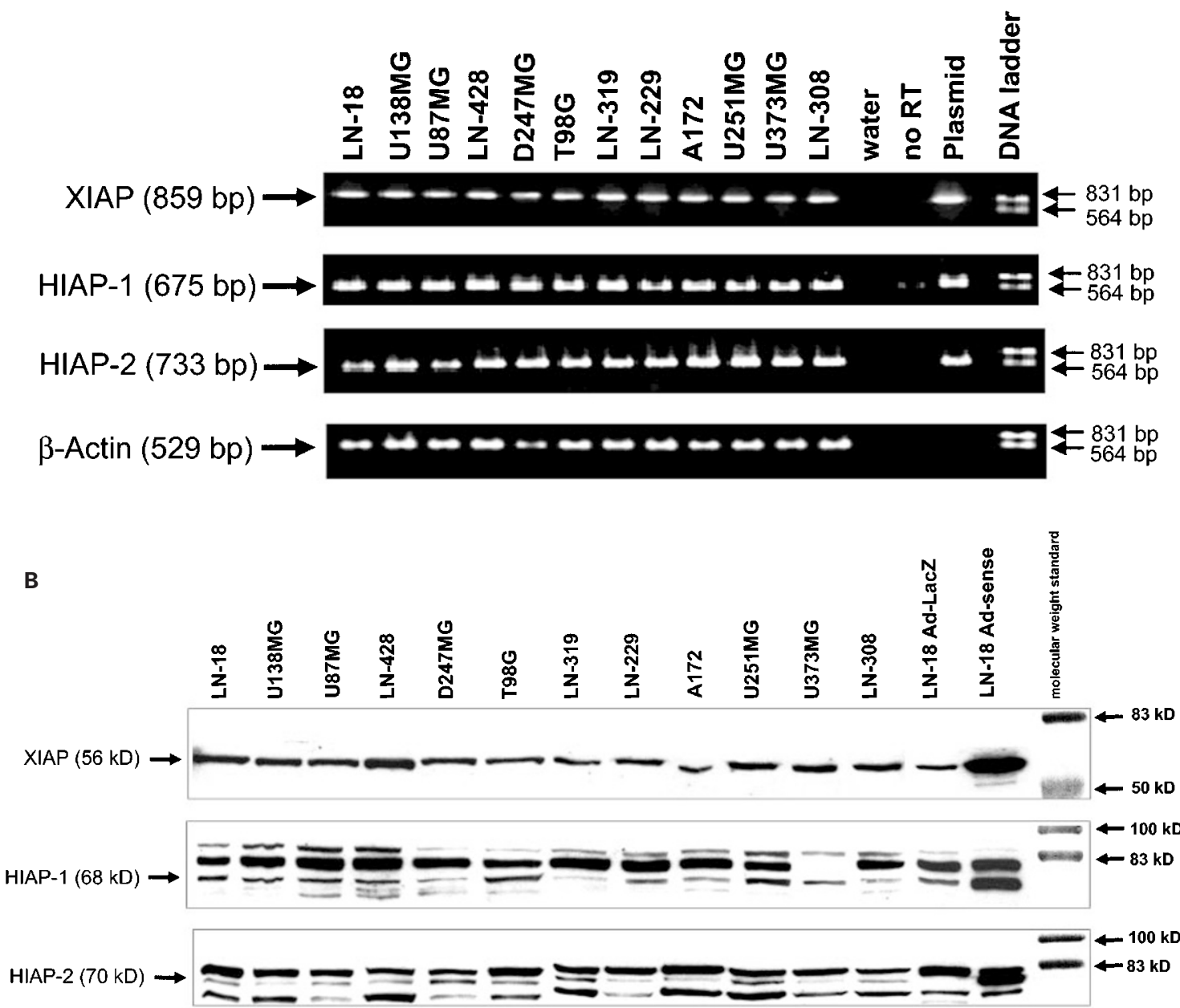

Figure 1 Expression of XIAP, HIAP-1 and HIAP-2 mRNA and protein in human malignant glioma cell lines. Total RNA and soluble protein lysates were prepared and RT - PCR (A) or immunoblot analysis (B) performed as described in Materials and Methods. The predicted sizes of the PCR fragment are given in Table 1. (A) the cDNA plasmids served as a positive control for the PCR (right outer lane), and $\beta$-actin mRNA was amplified as a house-keeping gene. (B) LN-18 cells infected with the lac-Z or the respective IAP-encoding adenoviral vectors served as positive controls for the immunoblots (right outer lanes). The predicted protein sizes are $56 \mathrm{kDa}$ for XIAP, $68 \mathrm{kDa}$ for HIAP-1 and $70 \mathrm{kDa}$ for HIAP-2 
targets for proteolytic degradation during apoptosis. These experiments were performed because, e,g., the antiapoptotic BCL-2 protein has been shown to undergo caspasedependent proteolysis during apoptosis. ${ }^{26}$ We find that IAP are not cleaved as a result of CD95L-induced caspase activation (Figure 2A). In parallel experiments, we confirmed that $\operatorname{PKC} \delta$, a known substrate for caspases, was cleaved under these conditions (Figure 2A). Moreover, we have demonstrated earlier that cleavage of caspases 8 and 3 as well as poly-(ADP)-polymerase started 3-4 $\mathrm{h}$ after CD95

Table 1 Primer sequences (S sense, AS antisense) and RT-PCR amplification conditions for human XIAP, HIAP-1, HIAP-2 and $\beta$-Actin

\begin{tabular}{|c|c|c|c|c|c|c|c|}
\hline MRNA & Sequence & Nucleotides & Denaturation & Annealing & Amplification & Cycles & Size [bp] \\
\hline XIAP-S & 5'-GGCCATCTGAGACACATGCAG-3' & $425-445$ & $95^{\circ} \mathrm{C} / 45 \mathrm{~s}$ & $55^{\circ} \mathrm{C} / 45 \mathrm{~s}$ & $72^{\circ} \mathrm{C} / 7 \mathrm{~min}$ & 35 cycles & 859 \\
\hline XIAP-AS & 5'-GCATTCACTAGATCTGCAACC-3' & $1263-1283$ & $95^{\circ} \mathrm{C} / 45 \mathrm{~s}$ & $55^{\circ} \mathrm{C} / 45 \mathrm{~s}$ & $72^{\circ} \mathrm{C} / 7 \mathrm{~min}$ & 35 cycles & \\
\hline HIAP1-S & $5^{\prime}$-TTGGAAGCTACCTCTCAGCC-3' & $1036-1056$ & $95^{\circ} \mathrm{C} / 45 \mathrm{~s}$ & $55^{\circ} \mathrm{C} / 45 \mathrm{~s}$ & $72^{\circ} \mathrm{C} / 7 \mathrm{~min}$ & 35 cycles & 761 \\
\hline HIAP1-AS & 5'-СTGCATTTTCATCTCCTGGGC-3' & $1776-1796$ & $95^{\circ} \mathrm{C} / 45 \mathrm{~s}$ & $55^{\circ} \mathrm{C} / 45 \mathrm{~s}$ & $72^{\circ} \mathrm{C} / 7 \mathrm{~min}$ & 35 cycles & \\
\hline HIAP1-S nested & 5'-CСАСАСАСТCATTACTTCCGG-3' & $1083-1103$ & $95^{\circ} \mathrm{C} / 45 \mathrm{~s}$ & $55^{\circ} \mathrm{C} / 45 \mathrm{~s}$ & $72^{\circ} \mathrm{C} / 7 \mathrm{~min}$ & 35 cycles & 675 \\
\hline HIAP1-AS nested & 5'-GGTAACTGGCTTGAACTTGACG-3' & $1736-1757$ & $95^{\circ} \mathrm{C} / 45 \mathrm{~s}$ & $55^{\circ} \mathrm{C} / 45 \mathrm{~s}$ & $72^{\circ} \mathrm{C} / 7 \mathrm{~min}$ & 35 cycles & \\
\hline HIAP2-S & $5^{\prime}$-CTGCCTCCCAAAGACTTTTCC-3' & $1170-1190$ & $95^{\circ} \mathrm{C} / 45 \mathrm{~s}$ & $55^{\circ} \mathrm{C} / 45 \mathrm{~s}$ & $72^{\circ} \mathrm{C} / 7 \mathrm{~min}$ & 35 cycles & 733 \\
\hline HIAP2-AS & $5^{\prime}$-GGACAGTTGGGAAAATGCCTC-3' & $1882-1902$ & $95^{\circ} \mathrm{C} / 45 \mathrm{~s}$ & $55^{\circ} \mathrm{C} / 45 \mathrm{~s}$ & $72^{\circ} \mathrm{C} / 7 \mathrm{~min}$ & 35 cycles & \\
\hline hu $\beta$-ACTIN-S & 5'-TGTTTGAGACCTTCAACACCC-3' & $409-429$ & $95^{\circ} \mathrm{C} / 45 \mathrm{~s}$ & $55^{\circ} \mathrm{C} / 45 \mathrm{~s}$ & $72^{\circ} \mathrm{C} / 7 \mathrm{~min}$ & 35 cycles & 529 \\
\hline hu $\beta$-ACTIN-AS & 5'-AGCACTGTGTTGGCGTACAG-3' & $918-937$ & $95^{\circ} \mathrm{C} / 45 \mathrm{~s}$ & $55^{\circ} \mathrm{C} / 45 \mathrm{~s}$ & $72^{\circ} \mathrm{C} / 7 \mathrm{~min}$ & 35 cycles & \\
\hline
\end{tabular}

A

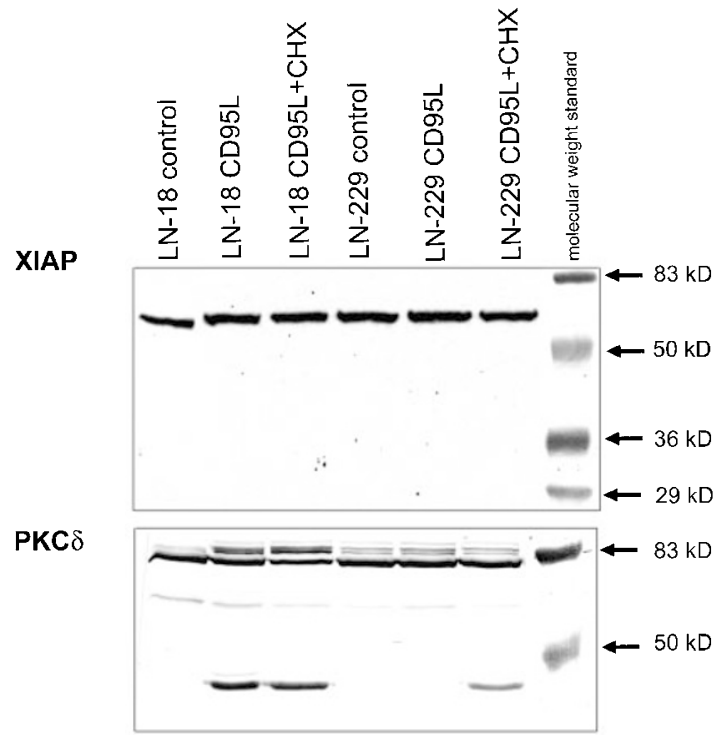

B
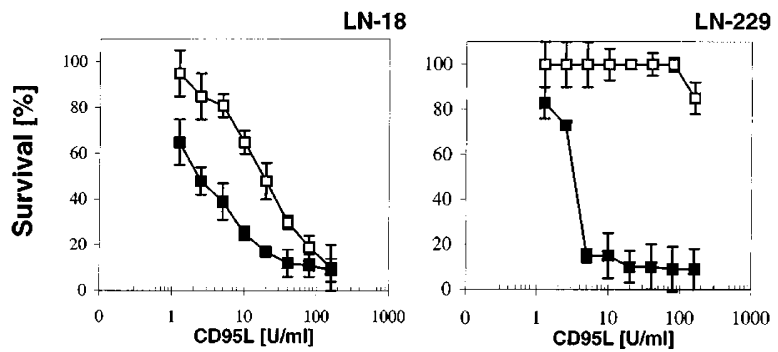

C
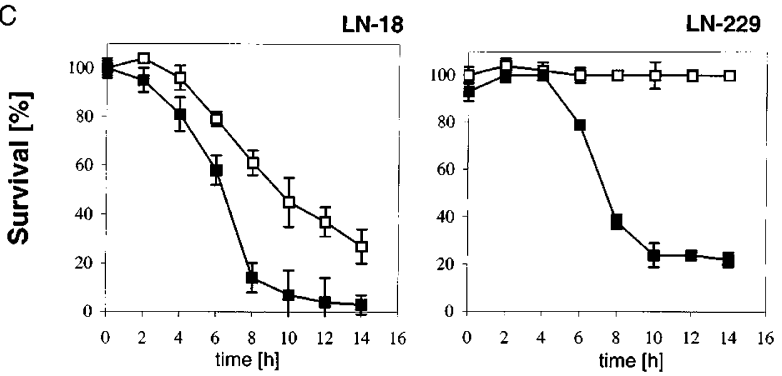

D

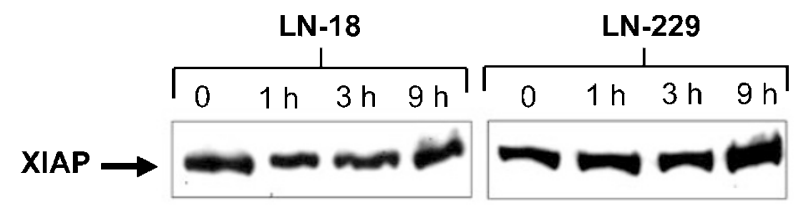

Figure 2 IAP proteins are not cleaved during CD95L-induced apoptosis and inhibition of IAP protein synthesis does not mediate CHX-induced potentiation of CD95L-induced apoptosis. (A) LN-18 and LN-229 were incubated with CD95L $(80 \mathrm{U} / \mathrm{ml})$ in the absence or presence of CHX $(10 \mu \mathrm{g} / \mathrm{ml})$ for $6 \mathrm{~h}$. Immunoblot analysis for XIAP and PKC $\delta$ was performed as described in Materials and Methods. XIAP was not cleaved whereas PKC $\delta$ was processed to yield a $40 \mathrm{kDa}$ proteolytic fragment. Similar to XIAP, the levels of HIAP-1 and HIAP-2 proteins were unchanged under these conditions (data not shown). Further, there was also no cleavage of XIAP at 2 or $24 \mathrm{~h}$ after exposure to CD95L and CHX (data not shown). (B) LN-18 and LN-229 cells were exposed to increasing concentrations of CD95L in the absence (open squares) or presence (filled squares) of $\mathrm{CHX}(10 \mu \mathrm{g} / \mathrm{ml})$. Survival was assessed by crystal violet staining. Data are expressed as mean percentages of survival and S.D. ( $n=3)$. (C) LN-18 or LN-229 cells were exposed to CD95L $(80 \mathrm{U} / \mathrm{ml})$ in the absence (open squares) or presence (filled squares) of CHX (10 $\mu \mathrm{g} /$ $\mathrm{ml}$ ) for various time intervals. Data are expressed as mean percentages and S.D. ( $n=3)$ relative to untreated controls or controls treated with $\mathrm{CHX}$ alone, determined as in B. (D) LN-18 or LN-229 cells were untreated or exposed to CHX $(10 \mu \mathrm{g} / \mathrm{ml})$ for 1,3 or $9 \mathrm{~h}$. XIAP levels were monitored by immunoblot analysis as outlined in Materials and Methods. Similarly, the levels of HIAP-1 and HIAP-2 proteins were unchanged within this time frame of CHX exposure (data not shown) 
stimulation of LN-18 and LN-229 cells. ${ }^{25}$ Potentiation by inhibitors of RNA and protein synthesis such as ActD or $\mathrm{CHX}$ is a typical feature of CD95L-induced apoptosis ${ }^{27}$ (Figure 2B and $\mathrm{C}$ ). This has been explained by the presence of cytoprotective proteins which are short-lived and therefore deficient when glioma cells are killed by CD95L under conditions of inhibited protein synthesis. To assess whether IAP represent these hitherto unidentified putative cytoprotective proteins, we monitored the levels of IAP after exposure of the glioma cells to $\mathrm{CHX}$. Figure 2D shows that the levels of XIAP remain stable within the time frame of the experiments, suggesting that a rapid loss of IAP does not mediate $\mathrm{CHX}$-induced sensitization of glioma cells to CD95L-induced apoptosis. Similar results were observed with the putative HIAP-1 and HIAP-2 proteins (data not shown).

\section{Adenoviral XIAP gene transfer}

Next, we asked for the possible role of IAP proteins in the resistance to apoptosis of human glioma cells. To this end, we performed adenoviral gene transfer experiments to express abundant XIAP in the glioma cells. The efficacy of the adenovirus-mediated gene transfer was analyzed by measuring $\beta$-galactosidase activity. Concentration response analyses revealed that exposure of the glioma cells for $16 \mathrm{~h}$ to $50 \mathrm{MOI}$ AdV-LacZ resulted consistently in $\beta$-galactosidase staining of more than $90 \%$ of the cells (data not shown). Strong expression of the virally encoded XIAP gene was confirmed by immunoblot analysis (Figure $3 \mathrm{~A}$ ). Note that transgene expression at the protein level was unaffected by $\mathrm{CHX}$ within the time frame of the experiment, consistent with Figure 2D. In earlier studies, ${ }^{25}$ we have shown that CD95L induced caspase 8 and caspase 3 processing in glioma cells at $4 \mathrm{~h}$ of treatment. Since IAP proteins are inhibitors of caspases, specifically of caspase $3,{ }^{14}$ we next asked whether XIAP inhibited the proteolytic cleavage of caspases 8 and 3 after CD95 triggering.

In the absence of $\mathrm{CHX}$, ectopic expression of XIAP inhibited the cleavage of both caspases 8 and caspase 3 when the glioma cells were exposed to CD95L (Figure 3B and C; left panels). Specifically, p18/caspase 8 was not detectable in XIAP-transduced cells, and p17/caspase 3 formation was blocked. In the presence of $\mathrm{CHX}$, caspase 8 cleavage was greatly attenuated in $\mathrm{LN}-18$ cells but largely unaffected in LN-229 cells. In contrast, CD95L-evoked caspase 3 cleavage to a p17 fragment was still prevented by XIAP in both cell lines. Interestingly, formation of the inactive p20/caspase 3 fragment was not detectable in LN18 cells but only in LN-229 cells. As previously reported, ${ }^{30}$ ectopic expression of XIAP promoted the accumulation of p20/caspase 3 , as a consequence of inhibition of autoprocessing.

Next, we analyzed caspase 3-like activity by measuring the cleavage of the fluorigenic substrate, Ac-DEVD-AMC. Ectopic expression of XIAP blocked DEVD-specific caspase activity (Figure 4A and $B$ ) and conferred strong protection from CD95-mediated cell death (Figure 4C and D). In contrast, adenoviral HIAP-1 or HIAP-2 gene transfer, despite good transgene expression (Figure 1B), had no significant inhibitory effect on CD95-mediated apoptosis in LN-18 or LN-229 human malignant glioma cells (data not shown).

A

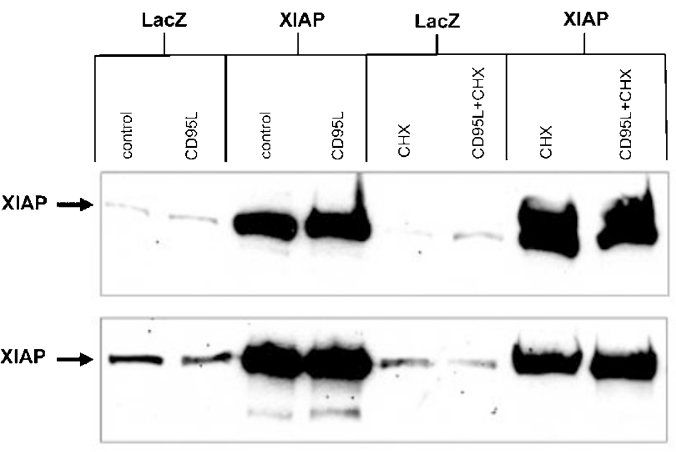

LN-229

B

LN-18

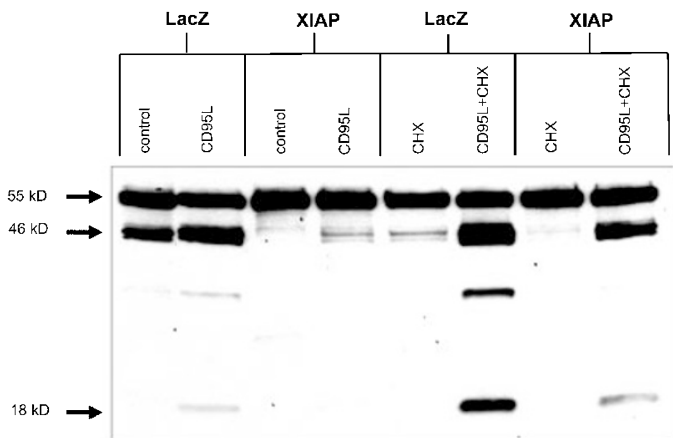

LN-229

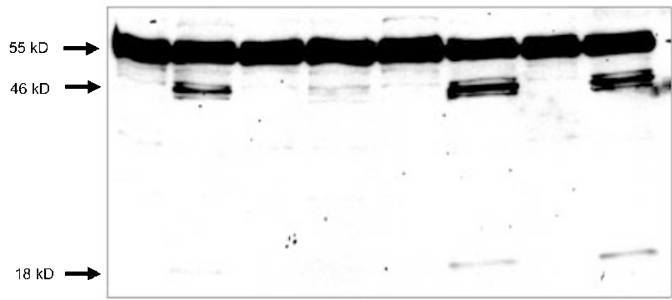

C

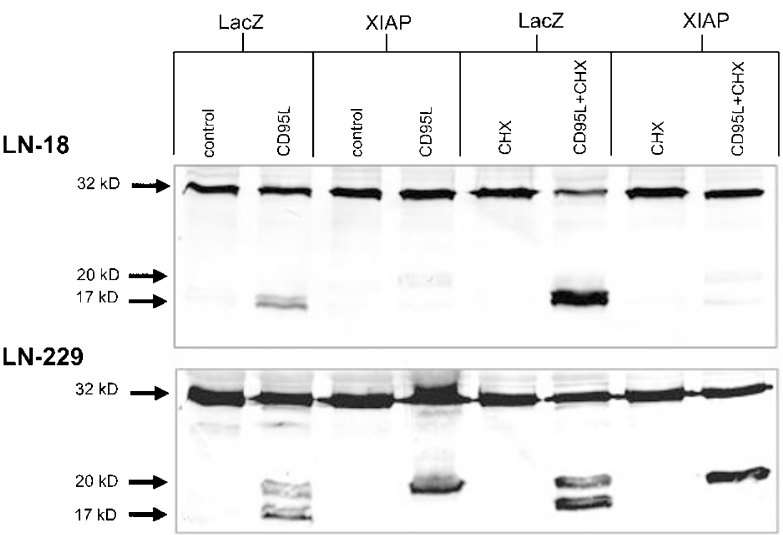

Figure 3 Adenoviral XIAP gene transfer: effects on CD95L-induced caspase 8 and 3 processing. (A-C) Glioma cells were infected with AdV-LacZ or AdVXIAP. At $6 \mathrm{~h}$ exposure to $\mathrm{CD} 95 \mathrm{~L}$ in the absence or presence of $\mathrm{CHX}(10 \mu \mathrm{g} / \mathrm{ml})$, the efficiency of infection $(\mathbf{A})$ as well as caspase $8(\mathbf{B})$ and $3(\mathbf{C})$ processing were studied by immunoblot analysis as described in Materials and Methods 

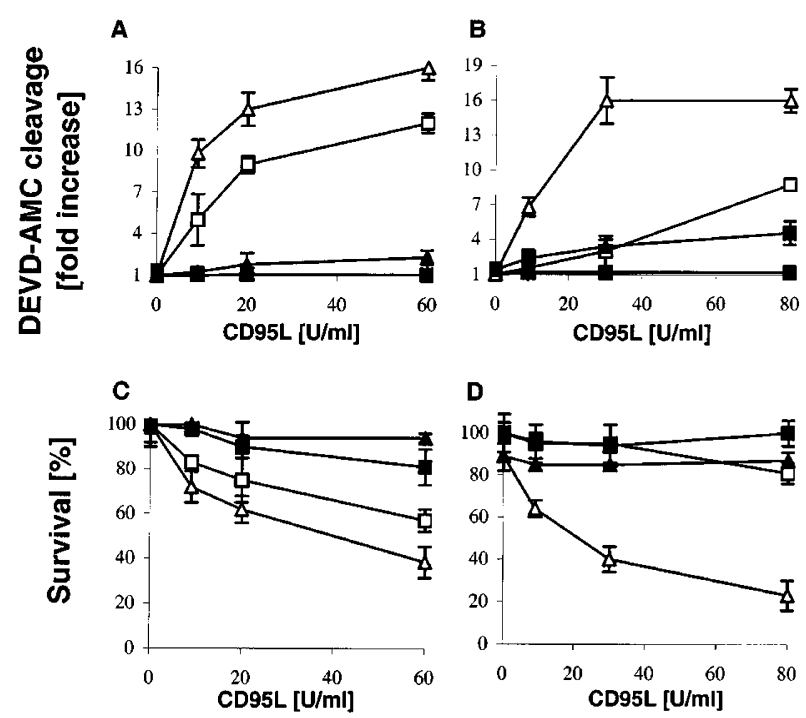

Figure 4 Effects of adenoviral XIAP gene transfer on CD95L-induced caspase 3-like activity and cell death. (A-D) LN-18 (A and C) or LN-229 (B and D) were infected with AdV-LacZ (open symbols) or AdV-XIAP (filled symbols) as described in Materials and Methods. The cell lines were exposed to $\mathrm{CD} 95 \mathrm{~L}$ in the absence (squares) or presence (triangles) of $\mathrm{CHX}(10 \mu \mathrm{g} / \mathrm{ml}$ ) and examined for caspase 3 activity at $6 \mathrm{~h}$ by DEVD-AMC cleavage (A and $\mathbf{B}$ ) or for survival at $16 \mathrm{~h}$ by crystal violet assay (C and $\mathbf{D}$ )

\section{Discussion}

CD95L-induced apoptosis is a promising strategy of cytokine therapy for malignant glioma. ${ }^{24}$ The IAP proteins constitute a novel family of antiapoptotic proteins which are currently explored for their possible role in development and during cancerogenesis. Here, we report that XIAP, HIAP-1 and HIAP-2 are widely expressed by glioma cell lines (Figure 1), suggesting that these proteins may play a role in the striking resistance of gliomas to the induction of apoptosis by radiotherapy and cancer chemotherapy. In contrast, NAIP was not expressed by glioma cells. The lack of NAIP expression in glioma cell lines in vitro is consistent with strictly neuronal NAIP expression in the rat brain in vivo. ${ }^{8}$

Next, we examined the role of IAP proteins in CD95mediated apoptosis of two human malignant glioma cell lines, LN-18 and LN-229. These cell lines differ in their requirement for concurrent inhibition of protein synthesis for the CD95L to induce apoptosis. ${ }^{27} \mathrm{LN}-18$ cells are highly sensitive to CD95L whereas $\mathrm{LN}-229$ cells require coexposure to CD95L and an inhibitor of protein synthesis, $\mathrm{CHX}$, to efficiently undergo apoptosis (Figure 2B and $\mathrm{C}$ ). The strong potentiation of CD95-mediated apoptosis by $\mathrm{CHX}$ indicates the constitutive expression of antiapoptotic proteins which normally interfere with transduction of an apoptotic signal after CD95 triggering. Figure 2D shows that IAP proteins are not identical to these unknown proteins since their levels of expression do not rapidly decline after exposure to $\mathrm{CHX}$.

Caspase-dependent proteolysis of various substrates has been shown to play an important role in CD95mediated apoptosis in all cell types examined so far, ${ }^{28,29}$ including glioma cells. ${ }^{25}$ Here, we show that XIAP is not a substrate for caspase-dependent proteolysis under conditions where caspases $8,3, \mathrm{PKC} \delta$ and PARP are processed (Figure 2A). ${ }^{25}$

Scaffidi and colleagues ${ }^{16}$ have delineated two types of CD95-dependent killing cascades where the amount of active caspase 8 generated at the death-inducing signalling complex (DISC) determines whether a mitochondriaindependent pathway (type I cells) or a mitochondriadependent pathway (type II cells) is used. Type 1 death involves sequential activation of caspase 8 and 3 and is not blocked by bcl-2 whereas type II death requires a mitochondrial step, most likely cytochrome c release, prior to caspase activation and is blocked by BCL-2. Based on the protective effect of $B C L-2$ and the parallel rather than sequential activation of caspases 8 and $3,{ }^{25}$ glioma cells would be classified as type II cells.

The inhibition of both caspase 8 and caspase 3 processing by XIAP in the absence of $\mathrm{CHX}$ would be consistent with the presence of an upstream caspase activity amenable to inhibition by XIAP, e.g., caspase 9 , which cleaves both caspases 8 and 3 , for the following reasons: (i) XIAP prevents caspase 8 processing (Figure 3 ) but does not directly interact with caspase $8^{13,30}$ and (ii) caspase 8 is not known to be cleaved by caspase 3 . This hypothesis is in line with a mitochondrial step in a type II CD95-mediated death of glioma cells ${ }^{16}$ and with the putative role for caspase 9 in triggering mitochondrial cytochrome $c$ release. ${ }^{31}$

When protein synthesis was inhibited, XIAP still prevented caspase 3 processing in both cell lines but was no more able to inhibit caspase 8 processing in $\mathrm{LN}$ 229 cells (Figure 3B). There was good correlation between the ability of XIAP to inhibit caspase 3 processing (Figure $3 C$ ), DEVD-cleaving caspase activity (Figure 4A and $B$ ) and cell death (Figure $4 C$ and $D$ ), suggesting that caspase 3 , once activated, may be the key executioner of CD95mediated apoptosis in glioma cells. The protective effect of $\mathrm{XIAP}$ in the presence of $\mathrm{CHX}$ could thus fully rely on the ability of XIAP to block caspase 3 processing. In contrast, caspase 8 processing per se is not sufficient to kill LN-229 cells after exposure to $\mathrm{CD} 95 \mathrm{~L}$ and $\mathrm{CHX}$, confirming the role of caspase 8 as a signalling caspase rather than killing caspase in this cell line.

We have shown that the viral caspase inhibitor, crm-A, inhibits the formation of p18/caspase 8 in both cell lines, the formation of p20/caspase 3 in LN-229 cells, and of p17/ caspase 3 in both cell lines, even in the presence of $\mathrm{CHX}{ }^{25}$ consistent with direction of caspase 8 (auto)processing by crm-A. BCL-2 inhibits the formation of p18/caspase 8 as well as crm-A. However, unlike crm-A, BCL-2 does not block the formation of p20/caspase 3 in $\mathrm{LN}-229$ cells in the presence of $\mathrm{CHX}$, but rather acts like $\mathrm{XIAP}$, be it direct or indirect, to inhibit caspase 3 autoprocessing. $^{25}$ Importantly, in the presence of $\mathrm{CHX}$, caspase 8 cannot be the only mediator of caspase 3 processing, since BCL-2 blocks caspase 8 processing but not the initial cleavage of caspase 3 to p20 in LN-229 cells co-exposed to CD95L and $\mathrm{CHX}{ }^{25}$ XIAP inhibits the formation of p18/caspase 8 in LN-18 cells in the absence and presence of $\mathrm{CHX}$ but not in $\mathrm{LN}-229$ cells in the 
presence of $\mathrm{CHX}$. Taken together, these data indicate a partial functional overlap of the protective effects of crm-A, bcl-2 and XIAP from CD95L-induced apoptosis in glioma cells and suggest the presence of a distinct pathway of death receptor-mediated apoptosis that is facilitated when protein synthesis is inhibited.

\section{Materials and Methods}

\section{Cell lines}

LN-18, U138MG, U87MG, LN-428, D247MG, T98G, LN-319, LN-229, A172, U251MG, U373MG and LN-308 human malignant glioma cells were kindly provided by Dr. N. de Tribolet (Laussanne, Switzerland). The cells were maintained in DMEM containing $10 \%$ foetal calf serum, $2 \mathrm{mM}$ glutamine and antibiotics. ${ }^{27,32,33} \mathrm{LN}-18$ and LN-229 cells expressing crm-A and puro control cell lines have been described. ${ }^{25}$

\section{RT - PCR}

RNA was prepared by the RNeasy Mini kit from Quiagen according to a standard protocol. RT-PCR was performed according to standard procedures as outlined previously, ${ }^{33}$ except that random primers were used instead of oligo $(\mathrm{dT})_{30}$ for first strand cDNA synthesis. A nested PCR protocol was used for the detection of HIAP-1 mRNA. Primer sequences and amplification conditions are summarized in Table 1. No signal was obtained when RT was omitted from the RT reaction.

\section{Immunoblot analysis}

Soluble protein lysates were obtained from subconfluent glioma cell cultures and SDS-PAGE with electroblotting performed as described. ${ }^{27}$ The following polyclonal antibodies were raised in rabbits: anti-human XIAP; anti-rat IAP (RIAP)-1, cross-reactive with HIAP-1; anti-RIAP-2, cross-reactive with HIAP-2; and anti-mouse NAIP. The caspase 8 antibody $\mathrm{C} 15$ (mouse monoclonal) was kindly provided by P.H. Krammer (Heidelberg, Germany). The caspase 3 antibody (mouse monoclonal) was obtained from Transduction Laboratories (Lexington, KY, USA). The PKC $\delta$ antibody (rabbit polyclonal) was obtained from Santacruz (Santa Cruz, CA, USA). The secondary antibodies, protein $A$ and anti-mouse IgG, were purchased from Amersham (Braunschweig, Germany). Enhanced chemiluminescence (ECL, Amersham) was used for detection.

\section{Adenoviral gene transfer}

Adenoviral vectors were generated using the previously described open reading frames for XIAP. HIAP-1 and HIAP-2. The open reading frames of the adenovirus vectors were sequenced to make sure that no inactivating mutations had occurred. Subconfluent cultures of LN18 or LN-229 cells were infected with supernatant of recombinant adenoviruses at a multiplicity of infection (MOI) of 50 . The cells were exposed to the infectious viral particles in medium without serum for $30 \mathrm{~min}$. Then, full medium was added for $16 \mathrm{~h}$. In AdV-LacZ infected cells, $\beta$-galactosidase activity was measured as described previously. ${ }^{34}$

\section{Caspase 3-like enzymatic activity}

The cells were seeded in 96 well plates (10 000 cells per well) and allowed to attach for $24 \mathrm{~h}$. Then the cells were infected with AdV-XIAP as described above using lacZ-expressing adenovirus as control. At
$16 \mathrm{~h}$ after infection, the cells were treated as indicated for $6 \mathrm{~h}$. The cells were lysed in buffer $(25 \mathrm{mM}$ Tris/ $\mathrm{HCl} \mathrm{pH} 8.0,60 \mathrm{mM} \mathrm{NaCl}$, $2.5 \mathrm{mM}$ eDTA, $0.25 \%$ NP40) for $10 \mathrm{~min}$ and then the substrate, acetylAsp-Glu-Val-Asp-chloromethylcoumarin (Ac-DEVD-AMC; $12.5 \mu \mathrm{M}$ ), diluted in PBS, added and incubated at $37^{\circ} \mathrm{C}$ for $10 \mathrm{~min}$. Caspase 3like activity was measured for $1 \mathrm{~h}$ using a CytoFluor 2350 Millipore fluorometer at $360 \mathrm{~nm}$ excitation and $480 \mathrm{~nm}$ emission wave lengths.

\section{Viability assay}

Glioma cell viability was measured by crystal violet staining. ${ }^{27}$ Briefly, the cell culture medium was removed and surviving cells stained with $0.5 \%$ crystal violet in $20 \%$ methanol for 20 min at room temperature. The plates were washed extensively under running tap water, air-dried and optical density values read in an ELISA reader at $550 \mathrm{~nm}$ wave length.

\section{Acknowledgements}

This study was supported by a grant from the Deutsche Forschungsgemeinschaft to MW (We 1502/3-2) and the IKFZ Tübingen.

\section{References}

1. Shen Y and Shenk TE (1995) Viruses and apoptosis. Curr. Opin. Gen. Develop. 5: $105-111$

2. Henderson S, Huen D, Rowe M, Dawson CD, Johnson G and Rickinson A (1993) Epstein-Barr virus-encoded BHFR1 protein, a viral homologue of Bcl-2, protects human $B$ cells from programmed cell death. Proc. Natl. Acad.Sci. USA 90: $8479-8483$

3. Green DRand Reed JC (1998) Mitochondria and apoptosis. Science 281:13091312

4. Mignotte B and Vayssiere JL (1998) Mitochondria and apoptosis. Eur. J. Biochem. 252: 1-15

5. Zhou Q, Krebs JF, Snipas SJ, Price A, Alnemri ES, Tomaselli KJ and Salvesen GS (1998) Interaction of the baculovirus anti-apoptotic protein p35 with caspases. Specifity, kinetics, and characterization of the caspase/p35 complex. Biochemistry 37: 10757-10765

6. Crook NE, Clem RJ and Miller LK (1993) An apoptosis-inhibiting baculovirus gene with a zinc finger-like motif. J. Virol. 67: 2168-2174

7. Roy N, Mahadevan MS, McLean M, Shutler M, Yaraghi Z, Farahani R, Baird S, Besner-Johnston A, Lefebvre C, Kang C, Salih M, Aubry H, Tamai K, Guan X, loannou P, Crawford TO, De Jong PJ, Surh L, Ikeda JE, MacKenzie A and Korneluk RG (1995) The gene for neuronal apoptosis inhibitory protein is partially deleted in individuals with spinal muscular atrophy. Cell 80: 167-178

8. Xu DG, Korneluk RG, Tamai K, Wigle N, Hakim A, Mackenzie A and Robertson GS (1997) Distribution of neuronal apoptosis inhibitory protein-like immunoreactivity in the rat central nervous system. J. Comp. Neurol. 382: 247-259

9. Liston P, Roy N, Tamai K, Lefebvre C, Baird S, Cherton-Horvat G, Farahani R, McLean M, Ideka JE, MacKenzie A and Korneluk RG (1996) Suppression of apoptosis in mammalian cells by NAIP and a related family of IAP genes. Nature 379: $349-353$

10. Duckett CS, Nava VE, Gedrich RW, Clem RJ, Van Dongen JL, Gilfillan MC Shiels H, Hardwick JM and Thompson CB (1996) A conserved family of cellular genes related to the baculovirus iap gene and encoding apoptosis inhibitors. EMBO J. 15: 2685-2694

11. Uren AG, Pakusch M, Hawkins CJ, Puls KL and Vaux DL (1996) Cloning and expression of apoptosis inhibitory protein homologs that function to inhibit apoptosis and/or bind tumor necrosis factor receptor-associated factors. Proc. Natl. Acad. Sci. USA 93: 4974-4978

12. Xu DG, Crocker SJ, Doucet JP, St. Jean M, Tamai K, Hakim AM, Ideka JE, Liston P, Thompson CS, Korneluk RG, MacKenzie A and Robertson GS (1997) Elevation of neuronal expression of NAIP reduces ischemic damage in the rat hippocampus. Nature Med. 3: 997-1004

13. Deveraux QL, Takahashi R, Salvesen GS and Reed JC (1997) X-linked IAP is a direct inhibitor of cell-death proteases. Nature 388: 300-303 
14. Roy N, Deveraux L, Takahashi R, Salvesen GS and Reed JC (1997) The c-IAP-1 and C-IAP-2 proteins are direct inhibitors of specific caspases. EMBO J. 16 6914-6925

15. Vucic D, Kaiser WJ, Harvey AJ and Miller LK (1997) Inhibition of reaper-induced apoptosis by interaction with inhibitor of apoptosis proteins (IAPs). Proc. Natl. Acad. Sci. USA 94: 10183-10188

16. Scaffidi C, Fulda S, Srinivasan A, Friesen C, Li F, Tomaselli KJ, Debatin KM Krammer PH and Peter ME (1988) Two CD95 (APO-1/Fas) signaling pathways. EMBO J. 17: 1675-1687

17. Baker SJ and Reddy EP (1996) Transducers of life and death: TNF receptor superfamily and associated proteins. Oncogene 12: 1-9

18. Chu ZL, McKinsey TA, Liu L, Gentry JJ, Malim MH and Ballard DW (1997) Suppression of tumor necrosis factor-induced cell death by inhibitor of apoptosis C-IAP2 is under NF- $\kappa$ B control. Proc. Natl. Acad. Sci. USA 94: 10057-10062

19. You M, Ku P, Hrdlicková R and Bose HR (1997) ch-IAP1, a member of the inhibitor-of-apoptosis protein family is a mediator of the antiapoptotic activity of the v-Rel oncoprotein. Mol. Cell. Biol. 17: 7328-7341

20. Ambrosini G, Adida C and Altgiere DC (1997) A novel anti-apoptosis gene, survivin, expressed in cancer and lymphoma. Nature Med. 3: 917-921

21. Adida C, Crotty PL, McGrath, Berrebi B, Diebold J, Altieri DC (1998) Developmentally regulated expression of the novel cancer anti-apoptosis gene survivin in human and mouse differentiation. Am. J. Pathol. 152: 43-49

22. Adida C, Berrebi D, Peuchmaur M, Reyes-Mugica M, Altieri DC (1998) Antiapoptosis gene, survivin and prognosis of neuroblastoma. Lancet 351:882-883

23. Seshagiri S and Miller LK (1997) Baculovirus inhibitors of apoptosis (IAPs) block activation of Sf-caspase-1. Proc. Natl. Acad. Sci. USA 94: 13606-13611

24. Weller M, Kleihues P, Dichgans J and Ohgaki H (1998) CD95 ligand: lethal weapon for malignant glioma? Brain Pathol. 8: 285-293

25. Wagenknecht B, Schulz JB, Gulbins E and Weller M (1998) Crm-A, bcl-2 and NDGA inhibit CD95L-induced apoptosis of malignant glioma cells at the level of caspase 8 processing. Cell Death Differ. 5: 894-900
26. Cheng HY, Kirsch DG, Clem RJ, Ravi R, Kastan MB, Bedi A, Ueno K and Hardwick JM (1997) Conversion of Bcl-2 to a Bax-like death effector by caspases. Science 278: $1966-1968$

27. Weller M, Frei K, Groscurth P, Krammer PH, Yonekawa Y and Fontana A (1994) Anti-Fas/APO-1 antibody-mediated apoptosis of cultured human glioma cells. Induction and modulation of sensitivity by cytokines. J. Clin. Invest. 94: 954-964

28. Los M, van de Craen M, Peening LC, Schenk H, Westerndorp M, Baeuerle P, DrögeW, KrammerPH, Fiers W and Schulze-OsthoffK(1995) Requirement of an ICE/Ced-3 protease for Fas/Apo-1 mediated apoptosis. Nature 375: 81 - 83

29. Enari M, Hug H and Nagata S (1995) Involvement of an ICE-like protease in Fasmediated apoptosis. Nature 375: 78-81

30. Deveraux QI, Natalie R, Stennicke HR, Van-Arsdale T, Zhou Q, Srinivasula SM, Alnemri ES, Salvesen GS and Reed JC (1998) IAPs block apoptotic events induced by caspase- 8 and cytochrome $c$ by direct inhibition of distinct caspases. EMBO J. 17: 2215-2223

31. LiP, Nijhawan D, Budihardjo I, Srinivasula SM, Ahmad M, Alnemri ES and Wang X (1997) Cytochrome $c$ and dATP-dependent formation of Apaf-1/caspase-9 complex initiates an apoptotic protease cascade. Cell 91: 479-489

32. Weller M, Malipiero UV, Aguzzi A, Reed JC and Fontana A (1995) Protooncogene $b c /-2$ gene transfer abrogates Fas/APO-1 antibody-mediated apoptosis of human malignant glioma cells and confers resistance to chemotherapeutic drugs and therapeutic irradiation. J. Clin. Invest. 95: 26332643

33. Rieger J, Naumann U, Glaser T, Ashkenazi A and WellerM (1998)APO2 ligand: a novel lethal weapon against malignant glioma? FEBS Lett. 427: 124-128

34. Price J, Turner D and Cepko C (1987) Lineage analysis in the vertebrate nervous system by retrovirus-mediated gene transfer. Proc. Natl. Acad. Sci. USA 84: $156-160$ 